\title{
Sole Proprietorship to Private Limited Company - A Journey of Daijiworld Media Private Limited
}

\author{
Velita Sibon Lobo ${ }^{1} \&$ K. Shivshankar Bhat ${ }^{2}$ \\ ${ }^{1}$ Research Scholar, College of Management and Commerce, Srinivas University, Mangalore, \\ India-575001 \\ Orcid ID: 0000-0001-9496-6049; Email: lobovelita@gmail.com \\ ${ }^{2}$ Research Professor, College of Management and Commerce, Srinivas University, \\ Mangalore, India-575001 \\ Orcid ID: 0000-0002-2144-1943. Email: bhatkss@yahoo.com
}

Area of the Paper: Management.

Type of the Paper: Case Study.

Type of Review: Peer Reviewed as per $|\mathrm{C}| \mathrm{O}|\mathrm{P}| \mathrm{E} \mid$ guidance.

Indexed In: OpenAIRE.

DOI: https://doi.org/10.5281/zenodo.5889773

Google Scholar Citation: $\underline{\text { IJCSBE }}$

\section{How to Cite this Paper:}

Lobo, Velita Sibon, \& Shivshankar Bhat, K., (2022). Sole Proprietorship to Private Limited Company - A Journey of Daijiworld Media Private Limited. International Journal of Case Studies in Business, IT, and Education (IJCSBE), 6(1), 14-25. DOI: https://doi.org/10.5281/zenodo.5889773

International Journal of Case Studies in Business, IT and Education (IJCSBE)

A Refereed International Journal of Srinivas University, India.

Crossref DOI : https://doi.org/10.47992/IJCSBE.2581.6942.0146

(C) With Authors.

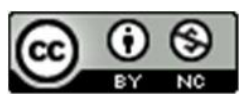

This work is licensed under a Creative Commons Attribution Non-Commercial 4.0 International License subject to proper citation to the publication source of the work.

Disclaimer: The scholarly papers as reviewed and published by the Srinivas Publications (S.P.), India are the views and opinions of their respective authors and are not the views or opinions of the S.P. The S.P. disclaims of any harm or loss caused due to the published content to any party. 


\title{
Sole Proprietorship to Private Limited Company - A Journey of Daijiworld Media Private Limited
}

\author{
Velita Sibon Lobo ${ }^{1}$ \& K. Shivshankar Bhat ${ }^{2}$ \\ ${ }^{1}$ Research Scholar, College of Management and Commerce, Srinivas University, Mangalore, \\ India-575001 \\ Orcid ID: 0000-0001-9496-6049; Email: lobovelita@ gmail.com \\ ${ }^{2}$ Research Professor, College of Management and Commerce, Srinivas University, \\ Mangalore, India-575001 \\ Orcid ID:0000-0002-2144-1943. Email: bhatkss@yahoo.com
}

\begin{abstract}
Purpose: The media industry is crucial in arranging images and discourses that have an impact on society. Many media companies are relying on social media to power their production and distribution processes. To thrive in a highly competitive world, innovation is seen as a critical component in overcoming the pressures of changing social, economic, and technical conditions. The relationship between management and innovation in the media sector is the primary subject of this research. It represents concerns that have an impact on the organizational structures, strategies, media content, and audience perception. Daijiworld Media is a Mangalore-based Indian media company that specializes in news and entertainment. through its website, TV channel, Youtube channel, weekly magazine, audio-visual studio, radio, IT company, and OTT platform. This paper examines the company's evolutionary growth, highlights the company's services and subsidiaries, investigates the company's strengths, weaknesses, challenges, and opportunities, uncovers the company's hiring and training procedures, examines its finance strategy and CSR initiatives, and assesses the impact of COVID on the company.

Methodology: This is an exploratory study based on primary data, and information is gathered by interviewing officials from Daijiworld, the Daijiworld Website, and news articles. Findings: Daijiworld Media is a Mangalore-based Indian media company that specializes in news and entertainment services through its website, TV channel, Youtube channel, weekly magazine, audio-visual studio, radio, IT company, and over-the-top (OTT) services, Throughout its twenty year history, this organization has researched the media and entertainment field and endeavored to respond to diverse customer expectations, from daijidubai to daijiworld, from daijiworld monthly magazine to audio-visual studio, from tv channel and radio to OTT. This company has studied the media and entertainment field and attempted to cater to various consumer demands during its twenty year history. The news on daijiworld is accurate, verifiable, and timely. It has content in all local languages to reach out to a wider range of audiences. They host different reality shows and help in the exposure of local talents. They constantly strive to come up with innovative concepts and content. Daijiworld Pvt Ltd is constantly striving to improve and adapt to market developments to be competitive.
\end{abstract}

Research limitations/implications: Complete information or research papers on Daijiworld Pvt Ltd are not available so contacting their multitasking busy officials for more information was little challenging.

Originality/value: This paper focuses on Daijiworld Media Private Ltd a local media and entertainment company.

Paper type: Case Study

Keywords: Sole Proprietorship, Private Limited company, Daijiworld, Media, Consumer, Audiences. 


\section{INTRODUCTION :}

The media industry plays a pivotal role in organizing images and discourses influencing the society. Many media are changing their production and distribution routines through social networks, to thrive in a highly competitive world, the ability to overcome the challenges of changing social, economic, and technological settings is viewed as a vital component of innovation. The relationship between management and innovation in the media sector is the primary subject of this research. It represents concerns that have an impact on strategies, organizational structures, media content, and public perception. Daijiworld Media is a Mangalore-based Indian media company that offers news and entertainment services, including the Website, TV channel, Youtube, weekly magazine, audio-visual studio, radio, IT company, and OTT [1]. On January 14, 2001, Walter Nandalike launched www.daijidubai.com with the primary goal of disseminating news from India's Coastal Konkan region [2]. Walter D'Souza Nandalike is the CEO and Founder of Daijiworld Media Pvt Ltd, a media company based in Mangaluru, Karnataka, India [3]. This website was created by Walter and a group of writers from the Daiji Dubai Writers Forum to promote and exchange knowledge of regional culture and traditions. In Konkani, daiji means relationship. In 2007, it was renamed www.daijiworld.com and transformed into a media corporation [2]. The fruitful 20 years of this company from daijidubai to daijiworld, from daijiworld weekly magazine to audio-visual studio, from TV channel and radio to OTT this way the company has explored the media and entertainment field and tried to cater to different needs of the audience. Daijiworld currently has 1.2 million unique visitors every month, according to estimates from almost 180 different countries Apart from trustworthy national news, the web has several columns covering Mangalore, Coastal Karnataka, Goa, Mumbai, and the Middle East, including daily news, events, special sections, cookery, and other information [2-4].

\section{REVIEW OF LITERATURE :}

It is obvious from the review study that appropriative innovation management is imperative for any sector to adapt itself to the changing business environment and the analysis of changing the organizational structure of Daijiworld Company is a typical case study of the problem. Below Table 1 contains the contributions of various researchers on Media and Entertainment.

Table 1: The contributions of various researchers on Media and Entertainment.

\begin{tabular}{|c|c|c|c|}
\hline S.I & Area & $\begin{array}{l}\text { Contribution } \\
\end{array}$ & Authors \\
\hline 1 & $\begin{array}{l}\text { Media and } \\
\text { Entertainm } \\
\text { ent } \\
\text { Industry }\end{array}$ & $\begin{array}{l}\text { The entertainment industry (also known as "Show Business") is a } \\
\text { tertiary sector of the economy that includes sectors like theatre, } \\
\text { films, fine arts, dance, music, television, radio, media, sports, } \\
\text { cultural events, and so on. This industry is constantly changing as a } \\
\text { result of discoveries and ideas. It is growing rapidly in terms of } \\
\text { revenue and volume, and it employs both creative and technical } \\
\text { staff. It saw rapid growth following liberalization, which resulted } \\
\text { in market internationalization and expansion. The evolution, } \\
\text { expansion, risks, problems, future trends, and influence of FDI on } \\
\text { the Indian entertainment industry are all examined in this paper. } \\
\text { This research investigates the influence of internationalization and } \\
\text { its possibilities for job creation. }\end{array}$ & $\begin{array}{c}\text { Lobo \& } \\
\text { Bhat,(2021) [5] }\end{array}$ \\
\hline 2 & $\begin{array}{c}\text { Transnation } \\
\text { al media } \\
\text { conglomera } \\
\text { tes }\end{array}$ & $\begin{array}{l}\text { The purpose of this review article is to obtain a comprehensive } \\
\text { understanding of the consequences of transnational media } \\
\text { conglomerates' (TNMCs) cross-border activities on cultural } \\
\text { integration, exchange, and even some resistance practices in other } \\
\text { countries. As a result, cross-border mobility of TNMCs would, to } \\
\text { some extent, produce tension between local traditional culture and } \\
\text { the trend of cultural homogenization. Still, different regions have } \\
\text { different attitudes and adjustment strategies in response to the } \\
\text { crisis, and they are attempting to export their values while profiting } \\
\text { from it. }\end{array}$ & $\begin{array}{c}\text { Liu., et al (2021) } \\
{[6]}\end{array}$ \\
\hline
\end{tabular}




\begin{tabular}{|c|c|c|c|}
\hline 3 & $\begin{array}{l}\text { Impact of } \\
\text { COVID on } \\
\text { the Media } \\
\text { industry }\end{array}$ & $\begin{array}{l}\text { The purpose of this research is to convey information concerning } \\
\text { the impact of the COVID-19 pandemic on the media and } \\
\text { entertainment industries. COVID19- National shutdowns have had } \\
\text { a profound impact on all sectors of the economy including the } \\
\text { media sector. }\end{array}$ & $\begin{array}{c}\text { Sunitha \& } \\
\text { Sudha, (2020) } \\
{[7]}\end{array}$ \\
\hline 4 & $\begin{array}{c}\text { New media } \\
\text { - economic } \\
\text { crisis }\end{array}$ & $\begin{array}{l}\text { New media has increased the scale of the media economy without } \\
\text { eroding conventional media's economic base. The current plight of } \\
\text { some media is primarily due to a short-term, cyclical reduction in } \\
\text { advertising revenue brought on by the economic crisis, as well as } \\
\text { the cumulative effects of media consolidation and financialization. } \\
\text { Enormous sums of capital were invested in the construction of } \\
\text { massive media conglomerates based on outrageously optimistic } \\
\text { estimates that future earnings will increase faster than the } \\
\text { developing network media economy and exceed the high profits } \\
\text { that defined the media in the past. When that utopian picture didn't } \\
\text { pan out, certain media organizations were in problems and were } \\
\text { stuck with unsustainable debts, but there was no media crisis per } \\
\text { such. }\end{array}$ & $\begin{array}{l}\text { Winseck D, } \\
(2010)[8]\end{array}$ \\
\hline 5 & $\begin{array}{l}\text { Mergers } \\
\text { and } \\
\text { ownership } \\
\text { of media } \\
\text { conglomera } \\
\text { tes }\end{array}$ & $\begin{array}{l}\text { According to this study, many media organizations rely on } \\
\text { advertising revenue to survive, as a result, the media outlet could } \\
\text { be influenced by corporate interests. The media behemoths benefit } \\
\text { greatly from the current global social system and the survival of } \\
\text { small media enterprises is challenging which forces them to merge } \\
\text { and consolidate their ownership }\end{array}$ & $\begin{array}{c}\text { Shah, A, (2009) } \\
\text { [9] }\end{array}$ \\
\hline 6 & $\begin{array}{c}\text { Global } \\
\text { media } \\
\text { conglomera } \\
\text { tes }\end{array}$ & $\begin{array}{l}\text { The article demonstrates how media ownership evolved from } \\
\text { media properties serving as a platform for personal and business } \\
\text { interests to conglomerates seeking economic "synergies" of } \\
\text { performance to a third stage driven by financial portfolio } \\
\text { diversification. These periods of foreign ownership of the media } \\
\text { coincide with the country's economic development. }\end{array}$ & $\begin{array}{l}\text { Chan-Olmsted } \\
\text { \& Chang, } \\
\text { (2003) [10] }\end{array}$ \\
\hline 7 & $\begin{array}{c}\text { A case } \\
\text { study on } \\
\text { The Sony } \\
\text { corporation }\end{array}$ & $\begin{array}{l}\text { This article examines Sony Corporation, a large multinational } \\
\text { media conglomerate focused on electronics, entertainment, music, } \\
\text { and gaming technologies. This study delves into the history and } \\
\text { development of the Sony Corporation. According to this study, a } \\
\text { company's business strategy and corporate culture are often a direct } \\
\text { reflection of the organization's growth and it also studies the } \\
\text { company from the standpoint of corporate strategy. Special } \\
\text { attention is paid to the concept of organizational culture. }\end{array}$ & $\begin{array}{l}\text { Gershon, } \\
\text { Kanayama, } \\
(2002)[11]\end{array}$ \\
\hline
\end{tabular}

\section{RESEARCH AGENDA :}

This study focuses on Daijiworld Media Private Limited, one of Mangalore's largest media conglomerates. This paper analyses the company's growth, strengths, weaknesses, opportunities, and challenges, the impact of COVID, and the company's long-term goals.

\section{RESEARCH GAP :}

The literature review on the media industry has several gaps for research, one of the major missing from the related works of literature was a concrete study on Local Media Conglomerates. This research is vital because we need to know the challenges faced by local media conglomerates for survival and growth.

\section{OBJECTIVES :}

The aims of the study are mentioned below.

1. To study the evolutionary growth of Daijiworld Media Private Limited.

2. To highlight the services and subsidiaries of Daijiworld Media Private Limited.

3. To explore the strengths, weaknesses, challenges, and opportunities. 
4. To find the hiring and training procedures.

5. To study their finance strategy and CSR initiatives.

6. To assess the impact of COVID on the company.

\section{RESEARCH METHODOLOGY :}

This is an exploratory study based on primary data, and information is gathered by interviewing officials from Daijiworld, the Daijiworld website, and news articles.

\section{HISTORY AND GROWTH :}

On April 1st, 2000, a young man messaged his pals to tell them that he had launched a website called daijidubai.com, and his friends responded that they couldn't open it. It was supposed to be an April Fool joke, but the young man was so taken aback by the response that he decided to launch a real website and this young man is Mr. Walter Nandalike, the brain behind and founder of the company, daijiworld.com (then called daijidubai.com). Mr. Walter took initiative and with a lot of dedication acquired computer knowledge and spent months perfecting the skills, which was a revolution in the field of journalism in the coastal region of Karnataka [2][12].

It became a media firm in March 2007 under the name Daijiworld Media Pvt Ltd. Daijiworld operates the Daijiworld TV channel, which is available $24 \times 7$. On May 9th, a test transmission was broadcast, and on June 16th, it began airing across coastal Karnataka via cable network and set-top boxes. The TV channel can also be accessed over the Internet and as an Android and iOS app. Daijiworld Weekly, an English-language weekly, is also published by the company [2][12].

An exclusive office in Kankanady, Mangalore, was established to meet the rising demand for news from India by NRIs, with 40 correspondents scattered over the twin districts of Dakshina Kannada and Udupi. Daijiworld went a step further and launched an office in Udupi on July 18, 2008. Daijiworld. In May 2009, Daijiworld launched Daijiworld Weekly, an English weekly newspaper, under the aegis of a new company called Daijiworld Publications Pvt Ltd. [2][12].

On the 20th anniversary of Daijiworld.com, Daijiworld and ATC Online have collaborated to develop the LOCAL WOOD OTT platform. The purpose of this OTT network is to stream local-language content including Tulu, Beary, Konkani, Kannada movies, and amusement videos in their native languages [12].

\section{THE COMPANY'S SUBSIDIARIES AND SERVICES :}

Daijiworld operates from 6 different locations Mangalore, Udupi, Kasargod, Bangalore, Mumbai, and Dubai but their offices are only in Mangalore and Udupi and the representatives work independently from other locations.

\section{DAIJIWORLD MEDIA PVT LTD (Branches/Operations)}

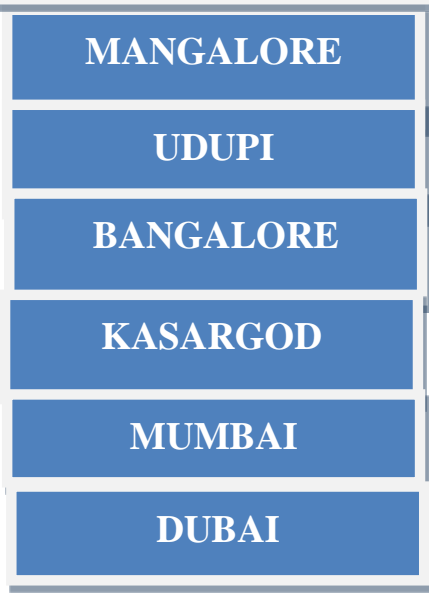

Fig. 1: Branches/Operations of Daijiworld Media Private Limited 


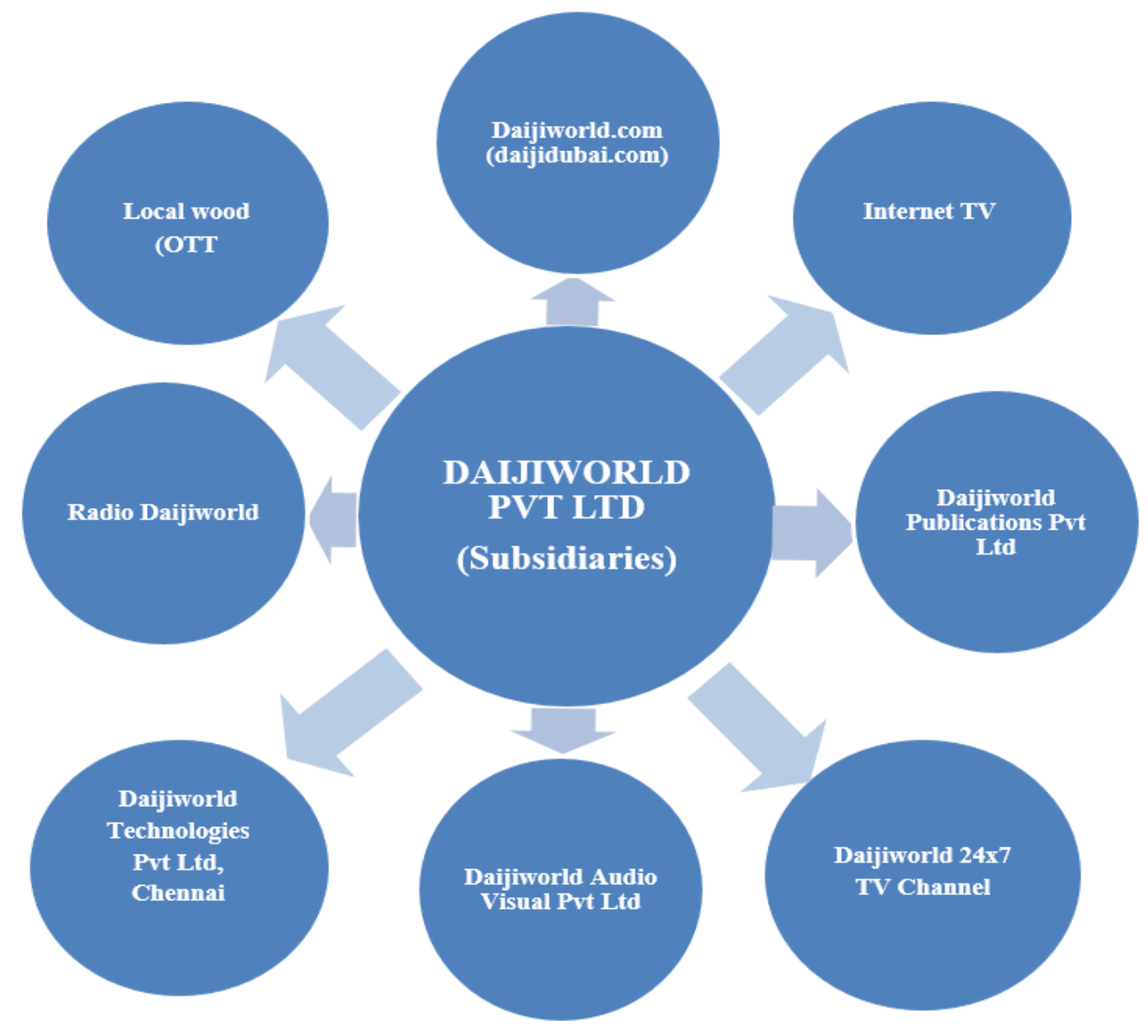

Fig. 2: Subsidiaries of Daijiworld Media Private Limited

Source: Compiled by Researcher

8.1 Daijiworld.com (daijidubai.com): The website daijidubai.com was created on April 1, 2000, and was renamed daijiworld.com in 2007. This website includes regional, national, and international news. The website contains various columns like obituaries(notice of death), recipes, short articles, charity(details of those who need help), matrimonial (short profiles to find partners), property(buy and sell properties), job vacancies, advertisements(paid advertisement of one's products and services), ask the doctor(your health-related queries will be answered by the doctors), greetings(best wishes ), astrology(forecasting of earthly and human events), love tributes, a connection to the Kannada version of the website, live TV (broadcasting what's on TV channel), articles, radio (directly connects to the radio daijiworld app, and red chillies (an exclusive column handled by Stan Ageria, this column contains his short stories) [2][12].

8.2 Internet TV - It is a method of delivering or broadcasting the content to the end audiences through the internet. Daijiworld Pvt Ltd broadcasts its content on its Website, Facebook pages, Youtube channel, Instagram TV, and Localwood app [2][12].

8.3 Daijiworld Publications Pvt Ltd - In May 2009, Daijiworld launched Daijiworld Weekly, an English weekly newspaper, under the banner of a new company called Daijiworld Publications Pvt Ltd. Financial, technological, artistic, legal, and marketing operations, among others, are all involved in publishing [12]. After the impact of COVID, this company ceased operations in 2021[13].

8.4 Daijiworld 24x7 TV Channel - The TV channel premiered in June 2014 and is available locally through cable and digital set-top boxes, as well as globally via the internet and an Android mobile app. It primarily caters to the news and entertainment interests of people from coastal Karnataka. This channel has content in all the regional languages and has both informative talks, reality shows, and various entertaining programmes [12][14]. 
8.5 Daijiworld Audio Visual Pvt Ltd - Daijiworld Audio- Visual Private Limited is a Private company that was founded on April 9, 2015. Daijiworld Studio is one of Mangaluru's most well-known and wellestablished recording studios. This studio was precisely constructed to meet the needs and expectations of clients, and it is suitable for all types of audio and video projects. The studio is sophisticated, with a cutting-edge facility that can meet the needs of the digital age in terms of originality, quality, and dependability. The studio has a state-of-the-art facility that, with its inventiveness, quality, and efficiency, can fully satisfy the needs of the digital age with supreme quality of audio and video services [13][15].

8.6 Daijiworld Technologies Pvt Ltd, Chennai -Daijiworld Technologies, based in Chennai, has been providing IT services since 2016. They are specialized in custom software development for mobile, web, and standalone back-office systems to meet our customers' business demands. To be a well-known and leading provider of IT services, projects, and solutions that are both cost-effective and of high quality. After the influence of COVID, this company was shut down in 2021 [16][17].

8.7 Radio Daijiworld - RADIO daijiworld is a free internet radio app for Android and iOS that caters to music fans from coastal Karnataka all over the world. It was launched on May 19, 2017. And this isn't your average FM station: the app-based online radio is precisely tailored to appeal to Konkani and Tulu music fans [18].

8.8 Local wood (OTT) - Daijiworld has been around for 20 years. To commemorate the occasion, they have established LOCAL WOOD, a first-of-its-kind OTT (over-the-top) platform for Tulu, Konkani, Beary, and Kannada entertainment content in coastal Karnataka in the year 2021. Localwood is a Rs 70 lakhs project that Daijiworld and ATC Online have worked on. The revenue from OTT will go straigh $t$ to the ATC group until the finances are settled, after which Daijiworld will fully own it. The Local wood OTT app is an excellent platform for launching Tulu, Konkani movies, web series, musical shows, and other content in both free and commercial versions. Local wood is an entertainment package in the local languages. It's a subscription-based streaming service that lets our customers view TV episodes, movies, and other content on any internet-connected device without advertisements [19].

\section{SWOC ANALYSIS :}

Strengths, Weaknesses, Opportunities and Challenges (SWOC) analysis is a simple but comprehensive approach to analyze an organization's positive and negative characteristics. It's an effective approach to use the skills to their advantage, address their flaws, grab opportunities, and plan to avoid potential threats. The table below analyses the internal and external factors of Daijiworld Media Private Limited [20-22].

Table 2: Strengths, Weaknesses, Opportunities, and Challenges of Daijiwold Media Pvt Ltd

\section{Strengths}

- The news on daijiworld is accurate, verifiable, and timely.

- There is faster up-gradation and adaptation to changes (modernization).

- It has content in all local languages to reach out to a wider range of audiences and it has content in all local languages to cater to a diverse audience.

- They host different reality shows and help in the exposure of local talents,

- They constantly strive to come up with innovative concepts and content to attract and delight the audiences.

- They have a high market share in the local media and entertainment sector,

- There is a strong brand awareness among the localities, social media marketing.

- They also assist in serving the community. 


\section{Opportunities}

- They can introduce a variety of reality shows and other content based on public interest,

- They can explore different platforms to reach the audience,

- They can offer a diverse range of programs for different age groups, notably for children's amusement

- They can strive to protect and preserve the environment.

\section{Challenges}

- Government regulations are not stable

- There may be piracy and copyrights issues

- There is a dearth of high-quality technology and types of equipment (because of financial constraints)

- There seem to be local competitors

- It is difficult to attain and retain audiences.

Source: Compiled by Researcher

\section{HIRING AND TRAINING :}

Growth is based on activities, it takes sweat, commitment, and hard efforts of the workforce to turn a dream into reality therefore a workforce plays a very important role in an organization. Daijiworld Pvt Ltd has a skillful, efficient, and multitasking workforce (both permanent and contract basis) of around sixty employees are assisting the company from different locations. If there is a vacancy, the information and advertisement will be posted on social media, after which the HR Manager will screen the applications and interview the candidates who have been chosen (mostly freshers and candidates okay with flexible hours will be preferred). Six months of training will be provided, along with a basic stipend and housing. One month's notice is required. If the employee wants to leave the company [23][24][25].

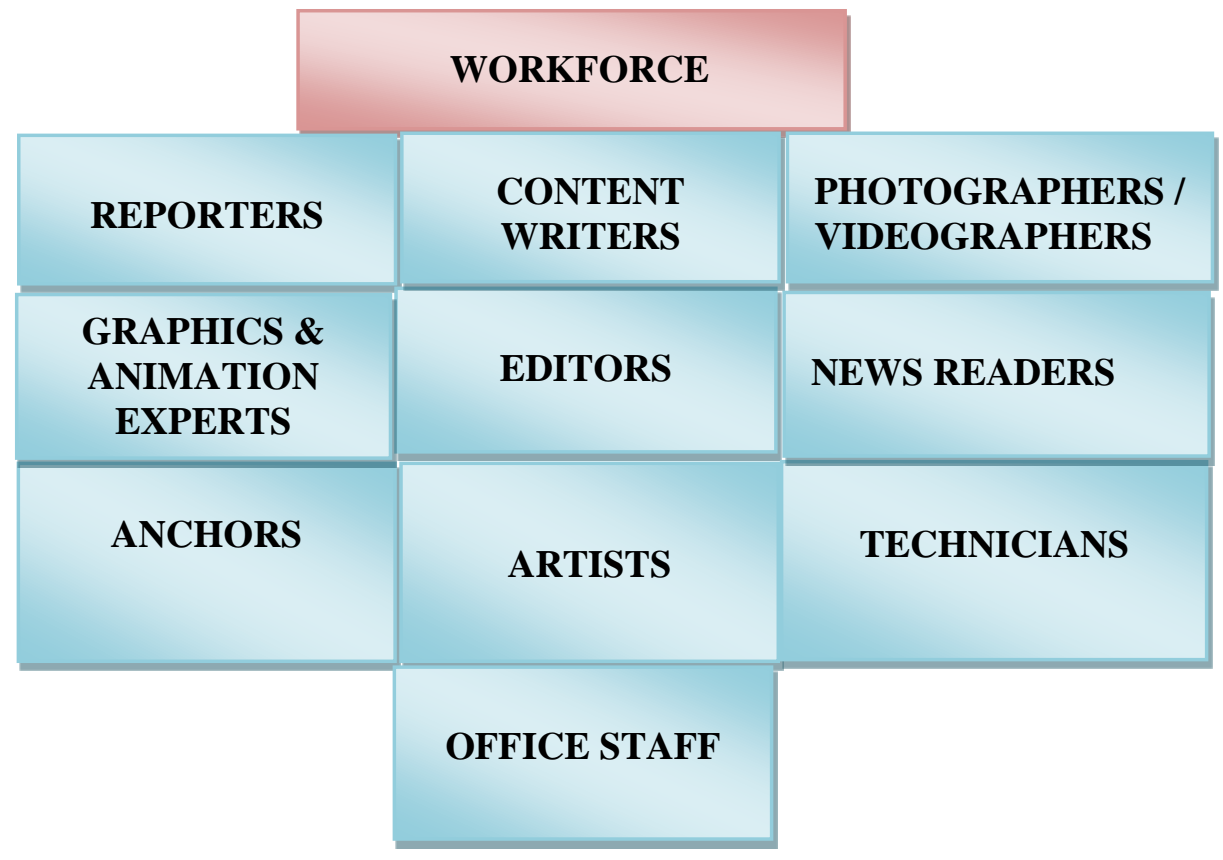

Source: Compiled by Researcher

Fig. 3: Different types of workforce required by Daijiworld Media Pvt Ltd

\section{FINANCIAL ACTIVITIES AND CSR INITIATIVES :}

Financials are defined as money management and include activities such as investment, borrowing, lending, budgeting, saving, and forecasting. Media companies often behave as non-profit organizations because their primary goal is to serve, inform, and educate society [26]. The channel pays a large fee to cable operators to be included on their network, and advertisements are their primary source of revenue [27]. They now earn money through social media as well, thanks to technological advancements and 
digitization [28]. Daijiworld Pvt Limited pays a large sum to the local cable operators, and their main source of revenue are advertisements along with studio, social media platforms like YouTube, FB, and now OTT subscription fees. If the company's income is insufficient to cover all of the expenses, the directors borrow money from their personal accounts [29][30].

Table 3: Inflow and outflow of funds of Daijiworld Media Pvt Ltd.

\begin{tabular}{|c|c|}
\hline Inflow of Funds & Outflow of Funds \\
\hline $\begin{array}{l}\text { - } \quad \text { Television advertisements } \\
\text { - } \quad \text { Website advertisements } \\
\text { - Studio recording and dubbing } \\
\text { - } \text { Sponsored programs } \\
\text { - } \text { OTTTube and Facebook page } \\
\text { - OTtent fees }\end{array}$ & $\begin{array}{l}\text { - Wages/salary } \\
\text { - Labour benefits } \\
\text { - Purchase of equipment } \\
\text { - Repairs/maintenance } \\
\text { - Refreshments } \\
\text { - Electricity and telecom bills }\end{array}$ \\
\hline
\end{tabular}

Source: Compiled by Researcher Daijiworld Pvt Ltd has acted as a link between contributors and the needy by posting their brief articles and videos on their websites and other social media platforms, allowing contributors to directly help them using the needy's bank account information. During these 20 years, Daijiworld Pvt Ltd has dispersed more than 22 crores to the needy through the donors, with approximately 500 members benefiting to date; they also aim to raise public awareness on various issues related to health, laws, and other public issues through their programs and media coverage, to fix the issues and work for the betterment of society.

\section{IMPACT OF COVID ON DAIJIWORLD PVT LTD :}

Consumers, businesses, and communities all across the world have been affected by the coronavirus (COVID-19) outbreak, which has caused widespread fear and economic hardship [31]. It's been almost a year since the COVID-19 outbreak wreaked havoc on the world's businesses. Organizations, including the media sector, must rethink how they operate. We must also recognize that, while most businesses are beginning to recover from this unanticipated catastrophe, the media industry still has a long way to go. COVID-19, like every other tragic disaster, has drawn attention to the media's role in public life. Traditional media witnessed an unexpected increase in viewing, despite decreasing ad revenue and a lack of fresh content, while digital media saw an increase in subscriptions [32]. Netflix, for example, received 16 million new subscribers during the lockdown. The new routine also changed the audience's consumption habits. During the lockdown, people experimented with new mediums and genres, as well as other types of information, influencing their choices and consumption patterns. As in prior crises, the need to stay informed and entertained has increased the demand for and consumption of information, and this trend is expected to continue [33][34].

The pandemic has resulted in several changes in Daijiworld Pvt Ltd, both positive and negative. Some negative effects include the closure of Daijiworld Publications Ltd and the closure of Daijiworld Technologies Pvt Ltd in Chennai, as well as staff reductions. Some positive effects include the creation of a variety of crowd-engaging, entertaining, and informative content such as informative programmes, virtual live shows, online singing competitions, and the introduction of the OTT platform LOCALWOOD.

\section{FINDINGS :}

Daijiworld Media is a Mangalore-based Indian media company that produces news and entertainment. services through its website, TV channel, Youtube channel, weekly magazine, audio-visual studio, radio, IT company, and over-the-top (OTT) services. From daijidubai to daijiworld, from daijiworld weekly magazine to audio-visual studio, from tv channel and radio to OTT, this company has analyzed the media and entertainment field and attempted to cater to various consumer demands during its 20year history. The news on daijiworld is accurate, verifiable, and timely. It has content in all local languages to reach out to a wider range of audiences. They host different reality shows and help in the exposure of local talents. They constantly strive to come up with innovative concepts and content. Their 
long-term goal is to open offices in Puttur and Kasargod, as well as settle the financials with their OTT service providers and fully own it.

\section{SUGGESTIONS :}

Daijiworld Media Private Ltd is constantly striving to improve and adapt to market developments to be competitive. They can introduce a variety of reality shows and other content based on public interest, they can use various platforms to reach out to the audience, they can provide a diverse range of programs for different age groups, particularly for children's entertainment, and they can work to protect and preserve the environment.

\section{CONCLUSION :}

Daijiworld Media is an Indian media firm situated in Mangalore that delivers news and entertainment through its website, TV channel, Youtube channel, weekly magazine, audio-visual studio, radio, information technology company, and over-the-top (OTT) services. Throughout its 20-year history, this organisation has analysed the media and entertainment field and endeavoured to respond to diverse customer expectations, from daijidubai to daijiworld, from daijiworld monthly magazine to audio-visual studio, from tv channel and radio to OTT. Wishing Daijiworld Pvt Ltd many more successful years, and may the firm grow in the years ahead, educating and entertaining people throughout the world.

\section{REFERENCES :}

[1] https://www.thehindu.com/todays-paper/tp-national/tp-karnataka/bishop-laudscontribution-of-internet-to-information-age/article3237109.ece retrieved on 11/9/2021.

[2] https://en.wikipedia.org/wiki/Daijiworld Media retrieved on 11/9/2021.

[3] https://www.daijiworld.com/news/newsDisplay?newsID=863879 retrieved on 11/9/2021.

[4] https://archive.today/20120729085111/http://www.blonnet.com/2006/12/19/stories/2006 121905742100. htm retrieved on 11/9/2021.

[5] Lobo, V. S., \& Bhat, K. S. (2021). An Analysis of Indian Entertainment Industry-Past, Present, and Future. International Journal of Management, Technology and Social Sciences (IJMTS), 6(2), 88-99.

Google Scholar $x^{7}$

[6] Liu, J., Liu, X., Tu, S., \& Xu, Z. (2021). Review of Cross-border Movements of Transnational Media Conglomerates. International Conference on Public Relations and Social Sciences (ICPRSS 2021), 586(1), 871-877.

Google Scholar Х

[7] Sunitha, S., \& Sudha, S. (2020). Covid-19 Conclusion: A Media and Entertainment Sector Perspective in India. Vichar Manthan, 8(24), 135-137.

Google Scholar $x^{\top}$

[8] Winseck, D. (2010). Financialization and the "Crisis of the Media": The Rise and Fall of (Some) Media Conglomerates in Canada. Canadian Journal of Communication, 35(3), 365-394.

Google Scholar $X^{\top}$

[9] Shah, A. (2009). Media conglomerates, mergers, the concentration of ownership. Global Issues.110.

Google Scholar $x^{\top}$

[10] Jung, J., \& Chan-Olmsted, S. M. (2005). Impacts of media conglomerates' dual diversification on financial performance. Journal of Media Economics, 18(3), 183-202.

Google scholar $x^{7}$ 
[11] Gershon, R. A., \& Kanayama, T. (2002). The sony corporation: A case study in transnational media management. International Journal on Media Management, 4(2), 105-117.

Google Scholar $x^{7}$

[12] https://www.daijiworld.com/news/newsDisplay?newsID=790991 retrieved on 11/9/2021.

[13] https://www.zaubacorp.com/company/DAIJIWORLD-PUBLICATIONS-PRIVATELIMITED/U22120KA2009PTC049275 http://studio.daijiworld.com/studio.aspx retrieved on $11 / 9 / 2021$.

[14] https://www.daijiworld.com/news/newsDisplay?newsID=242028 retrieved on 11/9/2021.

[15] http://studio.daijiworld.com/studio.aspx retrieved on 11/9/2021.

[16] http://daijitech.daijiworld.com/aboutUs.aspx retrieved on 11/9/2021. retrieved on 11/9/2021.

[17] https://www.zaubacorp.com/company/ESSE-DESIGNS-LLP/AAK-6969 retrieved on 11/9/2021.

[18] https://www.daijiworld.com/news/newsDisplay.aspx?newsID=452460 retrieved on 11/9/2021.

[19] https://www.daijiworld.com/news/newsDisplay?newsID=803745 retrieved on 11/9/2021.

[20] Holla, R. (2017). A Study on SWOC Analysis of Reliance Jio. International Journal of Engineering Research and Modern Education (IJERME), 2(1), (42-47).

Google Scholar $\chi^{\top}$

[21] Aithal, P. S., \& Kumar, P. M. (2015). Applying SWOC analysis to an institution of higher education. International Journal of Management, IT and Engineering, 5(7), 231-247.

Google Scholar $\chi^{\top}$

[22] Aithal, P. S. (2017). Company Analysis-The Beginning Step for Scholarly Research. International Journal of Case Studies in Business, IT and Education (IJCSBE), 1(1), 1-18. Google Scholar $X^{\top}$

[23] Hazelton, A. S., \& Terhorst, A. (2015). Legal and ethical considerations for social media hiring practices in the workplace. The Hilltop Review, 7(2), 53-59.

Google Scholar $X^{\top}$

[24] Sugrue, B., \& Clark, R. E. (2000). Media selection for training. Training and retraining: A handbook for business, industry, government, and the military, 208-234.

Google Scholar X

[25] Islam J. U., Rahman Z. (2016). ZEE Zindagi: Offering Value through Distinct Approach. South Asian Journal of Business and Management Cases, 5(2), 155-161.

Google Scholar X

[26] Rani, D. (2013). Privatization, convergence and broadcast regulations: A Case study of the Indian Television Industry. In The Asian conference on media and mass communication 2013-official conference proceedings, 1(1), 387-396.

Google Scholar $x^{\top}$

[27] Thomas, L. M., \& Mariswamy, H. K. (2017). Impact of Globalisation on Indian Media: a Study of 'Credibility'of Indian News Channels. Educational Research International, 6(1), 14-24.

Google Scholar $x^{\top}$

[28] Machill, M. (1998). Euronews: the first European news channel as a case study for media industry development in Europe and spectra of transnational journalism research. Media, Culture \& Society, 20(3), 427-450.

Google Scholar ${ }^{7}$

[29] Clark, G., Thrift, N., \& Tickell, A. (2004). Performing finance: The industry, the media, and its image. Review of International Political Economy, 11(2), 289-310. 
Google Scholar $x^{\top}$

[30] Tetlock, P. C. (2015). The role of media in finance. Handbook of Media Economics, 1(1), 701-721. Google Scholar X

[31] Seetharaman, P. (2020). Business models shifts: Impact of Covid-19. International Journal of Information Management, 54(1), 1-4.

Google Scholar $X^{\top}$

[32] Kabir, M., Afzal, M. S., Khan, A., \& Ahmed, H. (2020). COVID-19 pandemic and economic cost; impact on forcibly displaced people. Travel medicine and infectious disease, 35(1), 1-3. Google Scholar $x^{\lambda}$

[33] https://www.nagarro.com/en/blog/media-industry-covid19-impact-new-normal retrieved on $11 / 9 / 2021$.

[34] https://www.pwc.com/us/en/library/covid-19/coronavirus-impacts-media.html retrieved on $11 / 9 / 2021$.

$* * * * * * * * * * *$ 